\title{
EFFECTS OF SALINITY ON ION ACCUMULATION IN MAIZE (ZEA MAYS L. CV. BARI-7)
}

\author{
J.L. Karmoker, Sharmin Farhana and Parveen Rashid \\ Department of Botany, University of Dhaka, Dhaka-1000, Bangladesh
}

Key words: Salinity, $\mathrm{NaCl}$, Ion transport, Root, Shoot, Maize

\begin{abstract}
$\mathrm{NaCl}$ salinity in the range of 50 to $200 \mathrm{mM}$ increased $\mathrm{Na}^{+}$accumulation in the root and shoot of 7-, 14- and 21-day-old maize seedlings. The accumulation of $\mathrm{Na}^{+}$and $\mathrm{Cl}^{-}$increased but $\mathrm{K}^{+}$ accumulation decreased with the increase in $\mathrm{NaCl}$ concentration from 50 to $200 \mathrm{mM}$ in the root and shoot of maize in all the three ages.
\end{abstract}

Salinity is a common abiotic stress factor seriously affecting crop production in different regions, particularly in arid and semi-arid regions. Salinity is the single largest soil toxicity problem, and about $52.8 \%$ of the net cultivable area in the coastal and offshore areas of Bangladesh is affected by varying degrees of salinity (Karim et al. 1990). Salinity stress causes an imbalance in the uptake of mineral nutrients and their accumulation within the plants (Grattan and Grieve 1992). Osmotic stress, ion imbalances, particularly with $\mathrm{Ca}^{2+}$ and $\mathrm{K}^{+}$, and direct toxic effects of $\mathrm{Na}^{+}$and $\mathrm{Cl}^{-}$ions on the metabolic processes are the most important and widely studied physiological impairments caused by salt stress (Munns 2002, Munns et al. 2006). Maintaining a better nutrition with $\mathrm{K}^{+}$and $\mathrm{Ca}^{2+}$, while limiting $\mathrm{N}$ uptake, is a highly important trait contributing to salt-stress tolerance in plants. Consequently higher $\mathrm{K}^{+} / \mathrm{Na}^{+}$or $\mathrm{Ca}^{+} / \mathrm{Na}^{+}$ratios are typical to the tissues of salt tolerant varieties, and are often used as a screening parameter for identification of salt-stress tolerant varieties, and are often used as a screening parameter for identification of salt-stress tolerant varieties (Munns and James 2003, Song et al. 2006). To grow maize and other crops in the saline areas, understand physiological changes of various crops under salinity is important. This knowledge is useful for the plant breeders to develop salt tolerant crops. Therefore, the present investigation was undertaken to study the effect of $\mathrm{NaCl}$-induced salinity on the accumulation of ions in maize with a view to understand the mechanism of adaptation.

Seeds of maize (Zea mays L. cv. BARI-7) were collected from Bangladesh Agricultural Research Institute, Joydebpur, Gazipur. Seeds were sown and seedlings were raised in water culture for ion accumulation study. Modified half-strength Hoagland solution (Hoagland and Arnon 1950) was used as nutrient solution. The plants were subjected to different salinity treatments viz., $50,100,200 \mathrm{mM} \mathrm{NaCl}$ made in the halfstrength Hoagland solution. Half-strength Hoagland solution was used as control. The accumulation of ion was measured in roots and shoots of the seedlings at 7, 14, 21 days of salinity treatments. $\mathrm{Na}^{+}$and $\mathrm{K}^{+}$accumulation were measured using a flame photometer (Gallenkamp, Model FGA $330^{\circ} \mathrm{C}$ ) at wavelength of 589 and $767 \mathrm{~nm}$, respectively while $\mathrm{Cl}^{-}$ accumulation was measured following titrametric method (Begum et al. 1992). Three replicates were used for each measurement.

Effects of salinity on ion accumulation: In 7-day-old maize seedlings, $\mathrm{Na}^{+}$was increased 6.0 to $11.5 \%$ in the root (Fig. 1a) and 4.5 to $22.8 \%$ in the shoot (Fig. 1b) with the increase in salinity level from 50 to $200 \mathrm{mM} \mathrm{NaCl}$. Under salinity treatment, $\mathrm{K}^{+}$ accumulation was decreased in general and a maximum decrease of $41.2 \%$ in the root was noticed under $200 \mathrm{mM} \mathrm{NaCl}$ treatment (Fig. 1c). In the shoot, $\mathrm{K}^{+}$accumulation was 
also decreased by 10.9 and $20.7 \%$ in 100 and $200 \mathrm{mM} \mathrm{NaCl}$ treatment, respectively (Fig. 1d). In the root, $\mathrm{Cl}^{-}$accumulation was increased by 38.9, 43.7 and $49.2 \%$ over the control at 50, 100 and $200 \mathrm{mM} \mathrm{NaCl}$, respectively (Fig. 1e) while in the shoot it was increased up to $76.4 \%$ at $200 \mathrm{mM} \mathrm{NaCl}$ treatment (Fig. 1f).

In 14-day-old seedlings, maximum increase (14.5\%) of $\mathrm{Na}^{+}$accumulation in the root was found at $200 \mathrm{mM} \mathrm{NaCl}$ treatment (Fig. 1a) while in the shoot the same treatment caused a $22.9 \%$ increase (Fig. 1b). In the root, $\mathrm{K}^{+}$content was decreased to a maximum of $31.2 \%$ at $200 \mathrm{mM} \mathrm{NaCl}$ (Fig. 1c) while it decreased to a maximum of $17.6 \%$ in the shoot (Fig. 1d). Accumulation of $\mathrm{Cl}^{-}$increased by $52.9 \%$ and 2.7 -fold in the root (Fig. 1e) and by $24.8 \%$ and 2.1 -fold in the shoot (Fig. 1f) at 50 and $200 \mathrm{mM} \mathrm{NaCl}$ treatment, respectively.
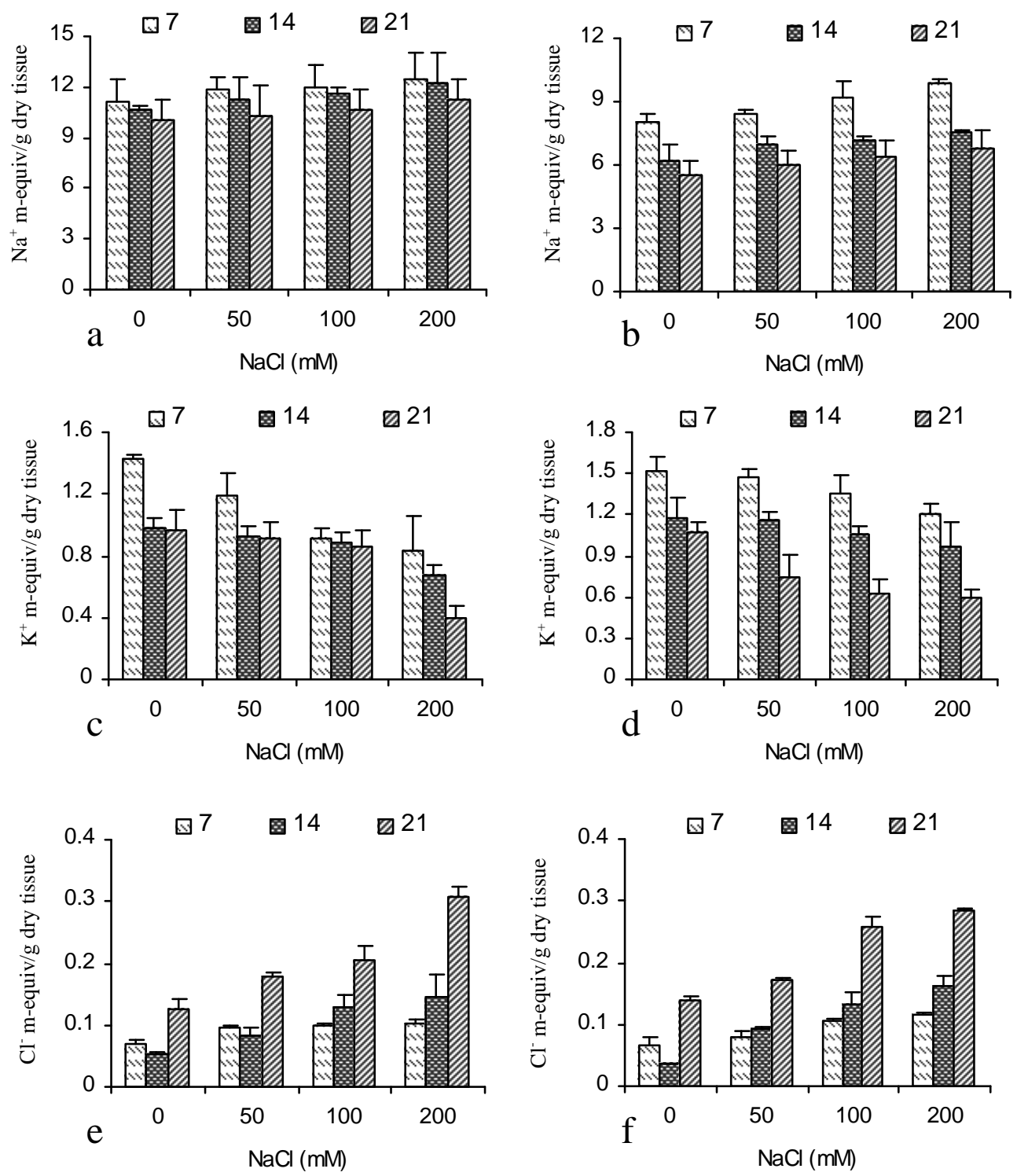
Fig. 1. Effects of different concentrations of $\mathrm{NaCl}$-induced salinity on $\mathrm{Na}^{+}$accumulation in the root (a) and shoot (b); $\mathrm{K}^{+}$accumulation in the root (c) and shoot (d) and $\mathrm{Cl}^{-}$accumulation in the root (e) and shoot (f) of 7-, 14- and 21-day-old seedlings of maize. Zero (0) represents control. Bar represents \pm standard error.

In 21-day-old seedlings, $\mathrm{NaCl}$ salinity stress caused a 2.3 to $11.5 \%$ increase in accumulation of $\mathrm{Na}^{+}$in the root (Fig. 1a) and 10.0 to $23.7 \%$ increase in the shoot as compared to control (Fig. 1b). A maximum decrease of $\mathrm{K}^{+}$content amounting to $58.9 \%$ was found in the root at $200 \mathrm{mM} \mathrm{NaCl}$ treatment (Fig. 1c) while the same treatment resulted in $45.2 \%$ decrease in $\mathrm{K}^{+}$content in the shoot (Fig. 1d). Accumulation of $\mathrm{Cl}^{-}$ increased by $41.3 \%$ to 2.4 -fold in the root at 50 and $200 \mathrm{mM} \mathrm{NaCl}$, respectively (Fig. 1e). In the shoot, $\mathrm{Cl}^{-}$accumulation increased by $24.8 \%$ and 2.1 -fold at 50 and $200 \mathrm{mM} \mathrm{NaCl}$ treatment, respectively (Fig. 1f).

In maize, $\mathrm{Na}^{+}$and $\mathrm{Cl}^{-}$accumulation in root and shoot increased following 50 to 200 $\mathrm{mM} \mathrm{NaCl}$ treatment while $\mathrm{K}^{+}$content in root and shoot decreased with the increase in salinity levels at all the three ages. Beck et al. (2004) found increased accumulation of $\mathrm{Na}^{+}$and strong inhibition of $\mathrm{K}^{+}$and $\mathrm{Ca}^{+2}$ accumulation in the root, stem and leaves with $\mathrm{NaCl}$-induced salinity. $\mathrm{Hu}$ and Schmidhalter (1997) also reported that $\mathrm{Na}^{+}$and $\mathrm{Cl}^{-}$ concentration in leaves and stem of wheat increased significantly whereas $\mathrm{K}^{+}$ concentration decreased with the increase in salinity. In NaCl-salt-stressed Melilotus segetalis, the concentration of $\mathrm{Na}^{+}$in stem was seven times higher than that of control whereas salinity reduced the concentration of $\mathrm{K}^{+}$in the root and the shoot (Romereo and Maranon 1996). In maize, $\mathrm{Na}^{+}$concentration of root was higher than in shoot with increasing salinity levels at 7,14 and 21 days of treatment (Fig. $1 \mathrm{a}$ and b). This result is in agreement with the work of Sagi et al. (1997) who found that in annual rye-grass, $\mathrm{Na}^{+}$ concentration in roots was higher than in shoots irrespective of the salinity level suggesting a restriction of $\mathrm{Na}^{+}$transport from the root to shoot. Chow et al. (1990) found that $\mathrm{Na}^{+}$is accumulated predominantly under saline condition. They suggested that $\mathrm{K}^{+}$ content in the cytoplasm must be maintained at a reference level for normal metabolism and this is an essential criterion for survival under salinity.

\section{References}

Beck, E., W. Netondo and J.C. Onyango. 2004. Sorghum and salinity. I. Response of growth, water relations, and ion accumulation to $\mathrm{NaCl}$ salinity. Crop Sci. 44: 797-805.

Begum, F., J.L. Karmoker, Q.A. Fattah and A.F.M. Moniruzzaman. 1992. The effect of salinity on germination and its correlation with $\mathrm{K}^{+}, \mathrm{Na}^{+}$and $\mathrm{Cl}^{-}$accumulation in germinating seeds of Triticum aestivum cv. Akbar. Plant Cell Physiol. 33: 1009-1014.

Chow, W.S., M.C. Ball and J.M. Anderson. 1990. Growth and photosynthetic response of spinach to salinity: Implications of $\mathrm{K}^{+}$nutrition for salt tolerance. Aust. J. Plant Physiol. 17: 563-578.

Grattan, S.R. and C.M. Grieve. 1992. Mineral element acquisition and growth response of plants grown in saline environments. Agric. Ecosyst. Environ. 38: 275-300.

Hoagland, D.R. and D.I. Arnon. 1950. The water culture method for growing plants without soil. Calif. Agric. Expt. Station Circular 347.

$\mathrm{Hu}, \mathrm{Y}$. and U. Schmidhalter. 1997. Interactive effects of salinity and macronutrient level on wheat. II. Composition. J. Plant Nutr. 20: 1169-1182.

Karim, Z., S.G. Hossain and M. Ahmed. 1990. Salinity problems and crop intensification in the coastal regions of Bangladesh. Soils and Irrigation Publication No. 33, Bangladesh Agric. Res. Council, Dhaka.

Munns, R. 2002. Comparative physiology of salt and water stress. Plant Cell Environ. 25: 239-250. 
Munns, R. and R.A. James. 2003. Screening methods for salinity tolerance: A case study with tetraploid wheat. Plant and Soil 253: 201-218.

Munns, R., R.A. James and A. Lauchli. 2006. Approaches to increasing the salt tolerance of wheat and other cereals. J. Expt. Bot. 57: 1025-1043.

Romereo, J.M. and T. Maranon. 1996. Allocation of biomass and mineral elements in Melilotus segetalis: Effects of $\mathrm{NaCl}$ salinity and plant age. New Phytol. 132: 565-573.

Sagi, M., A. Davrat, T. Kipnis and H. Lips. 1997. Ionic balance, biomass production and organic nitrogen as affected by salinity and nitrogen source in annual rye-grass. J. Plant Nutr. 20: 1291-1316.

Song, J.Q., X.R. Mei and H. Fujiyama. 2006. Adequate internal water status of $\mathrm{NaCl}$ - salinized rice shoots enhanced selective calcium and potassium absorption. Soil Sci. Plant Nutr. 52: 300304.

(Manuscript received on 9 December, 2006; revised on 9 September, 2008) 